\title{
Teacher training about Information and Communication Technologies: a diachronic perspective
}

\section{Formación de maestros en Tecnologías de la Información y la Comunicación: una perspectiva diacrónica}

\author{
PONCE GEA, Ana I. ${ }^{1}$ \\ RICO GÓMEZ, María L. ${ }^{2}$ \\ SOLA RECHE, José M. ${ }^{3}$ \\ GARCÍA VIDAL, Marcos ${ }^{4}$
}

\begin{abstract}
In this work, we define as a general objective to compare teacher training with the requirements of educational laws from a historical perspective, contextualising it from the 90s onwards in the Spanish context. We carried out a documentary analysis, around the treatment of ICT in legislation, initial and ongoing training and selective processes. The results show progressive incorporation of ICTs in all the areas, although with different rhythms.

key words: primary teacher training, teacher qualifications, information technology, communication technology.

Resumen

En este trabajo, definimos como objetivo general comparar la formación de los maestros con los requerimientos propios de las leyes educativas desde una perspectiva histórica, contextualizándolo desde la década de los 90 hasta hoy en el contexto español. Para ello, realizamos un análisis documental, alrededor del tratamiento de las TIC en legislación, formación inicial y permanente y procesos selectivos. Los resultados muestran una incorporación progresiva de las TIC en todas las áreas, aunque a ritmos diferentes.

Palabras clave: formación de docentes de primaria, competencias del docente, tecnología de la información, tecnología de la comunicación.
\end{abstract}

\section{Introduction}

The influence of information and communication technologies (ICT) on social changes has been a subject of frequent study, particularly in the present 21st century. The idea of a global and interconnected world has induced a deep reflection on the creation of new communication spaces, the influence on the construction of a collective identity and the new needs and opportunities around the reality of its progressive social extension. In the educational field, ICTs have been gaining ground, being incorporated both into educational laws (Manzano,

\footnotetext{
${ }^{1}$ Lecturer in Department of Didáctica General y Didácticas Específicas. University of Alicante. anaisabel.ponce@ua.es

${ }^{2}$ Lecturer in Department of Didáctica General y Didácticas Específicas. University of Alicante. marialuisa.rico@ua.es

${ }^{3}$ Associate Lecturer in Department of Didáctica General y Didácticas Específicas. University of Alicante. Current activity. Department. University of Alicante. jsola.reche@ua.es

${ }^{4}$ Tutor in Department of Métodos de Investigación y Diagnóstico en Educación I. UNED. marcos.garcia@elx.uned.es
} 
2015), and into the infrastructures of schools, in order to achieve digital literacy that includes initial and continuous training of students, especially in higher education (Agreda, Hinojo \& Sola, 2016).

However, the development of these laws and the mentioned literacy of students are only possible if teachers have sufficient training in technologies. In order to achieve this, it is necessary for teachers to acquire digital skills (Krumsvik, 2011) but not only for the sake of knowledge and use of ICT, but to gain access to the information available on the network in a collaborative way (Chib \& Wardoso, 2019). Thus, the simple management of digital tools and resources gives way to a complete integration both in professional and personal performance (Ferrari, 2013). Following this line, most authors have indicated that it implies the ability to select and use digital tools appropriately, within a technical, didactic-pedagogical and communicative knowledge of ICT, reaching digital literacy from different multimedia fields (Durán, Gutiérrez y Prendes, 2016).

At an international level, one of the first and most widely used digital competence training reference frameworks is the ICT competencies framework of the United Nations Educational, Scientific and Cultural Organization (UNESCO). Recently updated (UNESCO, 2019), it consists of 18 competencies organized around the six aspects of teachers' professional practice (understanding the role of ICT in educational policies, curriculum and assessment, pedagogy, application of digital skills, organization, administration, and professional learning), at three levels of pedagogical use of ICT by teachers. The theory states that teachers competent in ICT will provide quality teaching and will be able to effectively guide the development of the same competencies in students. In Spain, one of the priority areas in the ET2020 Strategic Framework for Education and Training is open and innovative education and training, with full incorporation into the digital age (Eurydice España-REDIE, 2018) Along this line, the National Institute of Educational Technologies and Teacher Training (Institute of Educational Technologies and Teacher Training, 2017) of the Ministry of Education, Culture and Sport of the Government of Spain has carried out a project with the objective to establish the Common Framework for digital teaching competence, which uses the competence model digital DIGCOM, prepared by the Institute for Prospective Technological Studies (IPTS) (Ferrari, 2013). INTEF designates five areas to ensure digital competence (information and information literacy, communication and collaboration, digital content creation, security and problem solving) that continue being present in the latest agreement of the 2020 Education Sectoral Conference. The proposed models, both at an international and national level, by different organizations and institutions feed, for their configuration, off the theoretical approaches made around digital competence. Although the contributions in this field are multiple, we will comment on just some of the most relevant and influential.

One of the first models of teaching digital competence is that of Hooper and Rieber (1995). According to it, in the process of introducing ICT in teaching, teachers go through a series of stages: familiarization, use, reorientation and evolution. The Norwegian model of digital competence elaborated by Krumsvik (2011), which broadly includes the definition of digital competence for teachers, adds to the purely technological aspects the didactic and pedagogical skills of the teaching staff. In this way, it establishes three levels: digital skills, didactic competence with ICT and learning strategies.

On the other hand, the TPACK (tecnological pedagogical content knowledge) model, by Koehler, Misshra, Kereluik, Seob and Graham (2014) is undoubtedly one of the most cited and used when trying to configure models for the integration of ICT. In this model, not only the domain of ICT is proposed, but it is required to project and design the curricular contents and the didactic methodologies in a parallel way. Its main advantage lies in the simultaneous consideration of disciplinary, pedagogical and technological knowledge. As one of the latest contributions, Kali, Sagy, Benichou, Atias and Levin-Peled (2019) have proposed what they call the TPeCS (Technology, Pedagogy, Content and Space) model. With it they support the need to reconceptualize the model and the adaptation of existing physical spaces, or the creation of new ones, for the proper use of ICT. 
There are numerous empirical works that are dedicated to the digital competence of teachers, especially since the last decade, adopting very different perspectives. In the first place, we find studies specifying the definition of what is understood by digital competence (McGarr \& MacDonagh, 2019; Padilla, Gámiz \& Romero, 2018); categorizing the digital competence and literacy of teachers (Castro \& Artavia, 2020) or treating digital competence in a given frame of reference (Cabero \& Palacios, 2020; Cabero, Romero \& Palacios, 2019). Secondly, there are also frequent works that defend the need to incorporate digital training for teachers due to the characteristics of the information and knowledge society (Tejada \& Pozos, 2018); due to their contribution to the professional development and learning of students (López, Campos, Aznar y Rodríguez, 2020) or for what digital training means for the school or even for the relationship with families (Peñalva, Napal \& Medioroz, 2018).

Third, there are studies related to the level of teacher training (Pozo, López, Fernández \& López, 2020) or studying the influence of factors on the acquisition and development of digital competence such as age (Pozo and others, 2020) or gender (Del Prete \& Cabero, 2020). Along the same lines, the level of digital competence of students in initial training of education studies has been analysed (Gutiérrez \& Serrano, 2016), as well as in the training plans of future teachers, in the teaching experience itself and from the student's perspective (Cabero, 2019; Ruiz, Medina, Pérez \& Medina, 2020). In the fourth place, works can be found in which an analysis of educational laws is carried out regarding teaching competence. Among them, stands out the study by Manzano (2015) which analyses the laws of Primary Education for the nineteen autonomous communities; and also the one by Prendes, Gutiérrez and Martínez (2018), which analyses the legislation in order to expand and complete information on the concept of digital competence itself.

Taking all that has been said as a basis, the purpose of this work is to make a comparison between the development of the digital competence required socially and that required by educational laws, the training of teachers and the access to the teaching career; As starting point the hypothesis that the requirements of the social and educational context must lead to transformations in the training of teachers and in the requirements for job performance is considered. In order to do so, we will adopt a diachronic perspective, from the General Law of Organization of the Educational System (LOGSE) (1990), which coincides in time with the generalization of the internet, in the 1990s.

According to what it has been said, we establish the following general objective in our research: "To compare the training of teachers with the requirements of educational laws from a historical perspective", specifying, for its resolution, three specific objectives: 1 . Analyse the consideration of ICT for learning in the different educational laws.

\section{Methodology}

\subsection{Investigation design}

The present study has been carried out using a qualitative methodology within the framework of an interpretive paradigm, in order to search for the deep meanings of the object of study (Martínez, Castellanos \& Chacón, 2014). It is a documentary analysis, with sources of diverse nature, for which we adopt the Valencian Community as a context.

Starting from the generalization of technologies from the 90s onwards and the chosen context, the selected sources are as following:

1. Educational laws: Organic Law of General Organization of the Educational System (LOGSE) (1990), Organic Law of Education (LOE) (2006), Organic Law for the Improvement of Educational Quality (LOMCE) (2013) and the 
Project of the Organic Law of Modification of the LOE (LOMLOE), as well as the corresponding Royal Decrees and Decrees.

2. Curriculums: The curriculum of Elementary School Teachers of the University of Alicante will be taken as a sample, analysing all the existing ones since 1990.

3. Selective processes announcements to access the Teaching career: calls made for the Primary Education Teachers from 1990 to the present in the Valencian Community.

All of the above has attended, for the analysis of the non-coincident elements, to the training and access of the generalist Primary Education teacher.

\subsection{Information analysis}

In order to carry out the qualitative analysis of the information, both classic and modern references have been used regarding the analysis of qualitative data (Huberman \& Miles, 2014; Martínez and others, 2014). The categories, reformulated during the analysis, are inductive-deductive, raising from the aforementioned research within the theoretical framework and a preliminary analysis of the sources. In Table 1, the meta-categories and categories used in the study are shown.

Table 1

Meta-categories and categories applied in the analysis.

\begin{tabular}{|c|c|c|}
\hline Treatment in laws & Treatment in training & $\begin{array}{l}\text { Tratamiento in selective } \\
\text { processes }\end{array}$ \\
\hline Law justification & Curriculum & Examination phase \\
\hline $\begin{array}{l}\text { Argument for the justification of the } \\
\text { law: Fundamental (F) Secondary o } \\
\text { Absent (S) in the preamble of the law }\end{array}$ & $\begin{array}{l}\text { Presence in the curriculum: Presence (P) } \\
\text { / Absence (A) in the curriculum } \\
\text { Nature of treatment: Specific matter. } \\
\text { (E) In other matters of the plan (A) } \\
\text { Duration of the subject: Quarterly (C) / } \\
\text { Annual (A) } \\
\text { Type of contents worked on: } \\
\text { Theoretical (T), theoretical-practical } \\
\text { (TP). }\end{array}$ & $\begin{array}{l}\text { Requirement: Requirement (R) / } \\
\text { No requirement (NR) of the } \\
\text { selection process. } \\
\text { Presence in the exam: Presence } \\
\text { (P)/ Absence }(A) \text { on the exam. } \\
\text { Nature of treatment: Specific (E) } \\
\text { /Connected to and area or other } \\
\text { didactic question (C). } \\
\text { Presence in the practical part: } \\
\text { Presence (P) / Absence }(A) \text { in the } \\
\text { practical part. }\end{array}$ \\
\hline Curricular purposes and elements & Permanent education & Contest phase \\
\hline $\begin{array}{l}\text { Stage objectives: Presence (P) } \\
\text { /Absence }(A) \text { in stage objectives. } \\
\text { Treatment in the law: Generalized (G) } \\
\text { / Punctual (P) } \\
\text { Incorporation into the field of } \\
\text { competence: Presence (P) / Absence } \\
\text { (A) of specific competence }\end{array}$ & $\begin{array}{l}\text { Specific training: Presence }(P) / \text { Absence } \\
(A) \text { of specific training }\end{array}$ & $\begin{array}{l}\text { Presence in the scale: Presence } \\
(P) / \text { Absence }(A) \text { in the scale } \\
\text { Nature of the score: Exclusive }(E) \text { / } \\
\text { Exchangeable }(I)\end{array}$ \\
\hline
\end{tabular}

Source: Prepared by the authors 


\section{Results}

When dealing with the results, we will use the specific objectives defined for the investigation as a reference.

\subsection{Importance of ICT in the different educational laws}

The main results of the analysis regarding the educational laws and the successive regulations of a regional nature are shown in Table 2.

Table 2

Results related to the ICT treatment in educational laws.

\begin{tabular}{|c|c|c|c|c|}
\hline & Law justification & \multicolumn{3}{|c|}{ Curricular purposes and elements } \\
\hline & Argument for justificación & Satge objectives & Treatment in the law & Field of competence \\
\hline LOGSE & S & A & P & A \\
\hline LOCE & F & P & G & P \\
\hline LOE & F & P & G & P \\
\hline LOMCE & F & P & G & P \\
\hline LOMLOE & F & P & & \\
\hline
\end{tabular}

Source: Prepared by the authors

According to what has been observed, the LOGSE can be understood as a beginning in the incorporation of technologies into educational legislation; which is consistent, on the other hand, with the chronological moment we are at the moment. The law recognizes the influence of technology on the changes that are taking place ("the changes in the cultural, technological and productive environment in Spanish society have accelerated"), although the purpose of its formulation does not focus on this question, which does not even appear as a stage objective in relation to Primary Education. Both in the Royal Decree 1006/1991, of June 14, and in the Decree 20/1992, of February 17, by the Valencian Government, there is a presence of ICT, although it is incorporated occasionally in some areas (Knowledge of the natural, social and cultural environment, artistic education and Mathematics). Here is mainly understood, though, as a resource for information search, data processing, etc.

The LOCE, although it will be repealed before its implementation, represents a change in relation to ICT, from the justification of the law in its preamble, which recalls the importance of the technological changes that are transforming society. In addition, according to the law, the need to adapt to the new European context, to which Spain has already fully incorporated, requires a greater degree of homologation and flexibility of the educational system, as well as the promotion in students of skills such as: communication, team working, identifying and solving problems with the help of technology.

Accordingly, the use of ICT is incorporated as a stage objective (j) Getting started in the use, for learning, of information and communication technologies"); The level of progression by cycles will be specified in Royal Decree 830/2003, of June 27.

Furthermore, along with the LOCE's proposals, it is worth highlighting the presence in the Royal Decree of the Plan for the Integration of Information and Communication Technologies in the Curriculum of the Different Areas. This Plan, coordinated, with curricular connection and evaluation object, implies the application of ICT in every curricular area, moving away from an anecdotal treatment and turning them into tools of indisputable utility for learning.

The LOE, of 2006, recognizes in the "accelerated evaluation of science and technology and the impact this evolution has on social development", one of the main reasons for the transformation of the educational model, 
being essential " everyone's access to the information and communication technologies". It is also committed to teacher training and the creation of open learning environments.

The ICT, worked in the different areas of knowledge, find new curricular support in the incorporation of basic competences, among which is

Information Processing and digital competence. Regarding stage objectives, the LOE and its Royal Decree $1513 / 2006$ maintain the objective formulated by the LOCE for Primary Education, adding to this the development of "a critical spirit in the messages they receive and elaborate." Decree 111/2007, of July 20, of the Valencian Community, in the same line, includes ICT in all areas, considering its usefulness for the search, selection, treatment of information and communication, as well as for its cooperative and communicative use in learning.

The LOMCE is committed to a change in the educational paradigm, based on three pillars, including ICT. This change in the paradigm comes hand in hand with competency learning, which establishes a context in which ICTs become important as facilitators or as part of a methodological change. The bet for key competences, now adopting the name "Digital Competence" for one of them, implies not only its treatment in all areas but also the obligation of assessment. This transversality issue will be assumed in Royal Decree 126/2014 and will be specified in Decree 108/2014, of the Valencian Community.

Although the LOMLOE is still in the Organic Law Project phase and, therefore, lacks further legislative development, it insists on the need to take into account the digital change that necessarily affects educational activity. In addition, it includes attention to the development of the digital competence of students at all stages, both through specific content and from a transversal perspective.

\subsection{Evolution of the presence and approach of ICT in study and training plans}

When presenting the results of this second specific objective, we will consider, on one side, the presence of ICT in the curriculums and, on the other, the attention that permanent training has paid them in the succession of educational laws.

In the first place, in Table 3, we include all that is related to the curriculum.

Table 3

Results related to the treatment of ICT in the curriculum

\begin{tabular}{|c|c|c|c|c|}
\hline & Presence & Nature & Duration & Content type \\
\hline 1992 plan & P & E & C $(4$ créd. $)$ & TP \\
\hline 1996 plan & P & E & C $(4.5$ créd. $)$ & TP \\
\hline 2000 plan & P & E $(4.5$ créd. $)$ & TP \\
\hline 2012 plan & P & E & C $(6$ créd. $)$ & TP \\
\hline
\end{tabular}

Source: Prepared by the authors

As can be seen from the results shown in Table 3, there are no obvious differences between the analysed categories. Thus, all the study plans for the training of teachers at the University of Alicante have incorporated, from the 90s, a specific subject on ICT. In every case, it is a four-month subject that includes the content of a theoretical-practical nature.

Under a more detailed internal analysis, yet other insights can be made. First, the name of the subjects themselves denotes a change in the conception of ICT and its role in the educational field: while 1992, 1996 and 2000 plans include as subject "New technologies applied to education"; the current plan, from 2012, incorporates the subject of "Curriculum development and digital classrooms in Primary Education". Second, and in line with the above, while "New technologies applied to education" is a subject shared between the 
Department of General Didactics and Specific Didactics and Computer Languages and Systems, that of "Curriculum development and digital classrooms in Primary Education" depends exclusively on the first of them. Third and last, together with the incorporation in the latest plans of topics such as the curricular articulation of ICT, digital classrooms, digital society, virtual contexts or educational software, the current subject presents a more practical approach, including evaluation.

Second, lifelong learning has also been incorporating technologies as part of its programs, with different importance according to current legislation. The LOGSE, in its preamble, indicates as an obligation of the educational administrations "the promotion of research and innovation in the curricular, methodological, technological, didactic and organizational fields". Along the same lines, the LOCE, in its chapter I, deals with permanent training programs, although without making explicit reference to ICT. It is the LOE that, for the first time, mentions the need to train the teaching body in digital skills. In this sense, article 102 of the aforementioned law indicates that, together with foreign languages, the use of ICT is an area in which educational administrations must promote permanent training. The LOMCE continues to delve into the issue of teacher training while adding article 111.bis which sets out the specifications for the digitization of the school. In addition, it indicates that the Administration will promote "a framework of digital teaching competence that guides the permanent training of teachers", an issue that seems to be specified in the LOMLOE.

The recognition of permanent training in ICT will also be present in Decree 231/1997, of September 2, of the Valencian Government, which regulates the creation, structure and operation of the Centres for Training, Innovation and Educational Resources of the Valencian Community, susceptible to further analysis.

\subsection{Treatment of ICT in the selection processes for the Teaching Career}

In relation to the third specific objective delimited, we present the results obtained from the review of the exam sessions to access the Teaching Career from 1990 to the present. To do this, we will adopt a generalized point of view, due to the continuity that prevails in the approaches, pointing out those changes that are of interest to our objective.

Regarding the "Examinations phase", all the calls share that digital training is not a requirement (NR) of access to the Teaching Career and that the presence of ICT, in the practical part, is limited to its inclusion in the didactic programming (in the event that current regulations understand them as a transversal element) (A). The most notable changes regarding this phase are found in the exam syllabus.

These exam syllabuses will be regulated successively by Order of September 9, 1993, Order ECl / 592/2007, of March 12, and Order EDU / 3136/2011, of November 15, the latter not yet implemented. In every case, we can speak of the presence of ICT (P), although with different treatment. The syllabus proposed in 1993, includes, in its general part, two topics that could be related to ICT: "Topic 15. Didactic resources: materials, printed, audiovisual and computer science. Criteria for selection and use. The library: functions according to the different reading purposes" and "Topic 19 . The media. Its importance in democratic society and in the formation of values, attitudes and habits of coexistence. Education for the critical use of the media".

Neither of the two topics deals specifically with ICT, for they are connected to other issues (C): resources, in the case of the first; and the media, in the case of the second. It is also worth mentioning a more technical perspective as can be shown from the use of the term "computer science", as opposed to the approaches embedded in desirable pedagogical models. The current agenda, from 2007, incorporates a specific topic (E) on ICT ("Topic 6. Information and communication technologies. Educational intervention for their use and application in different areas of knowledge"), also mentioned in Unit 25 the area of Mathematics (C) for data treatment. Although the statement of the topic could end up being translated into a theoretical enumeration of the contents, attention 
is paid to the "educational intervention" and the "application in the different areas of knowledge"; In other words, the 2007 proposal addresses ICTs specifically and within a pedagogical framework.

Finally, the agenda proposed in 2011, still not implemented today, eliminates the specific topic, treating ICT exclusively linked to other contents or areas of knowledge (C): as one more of the competences ("Topic 18. Basic competences referred to the field of expression and communication: Competence in linguistic communication, Mathematical competence, Cultural and artistic competence, Competence in the processing of information and digital competence, Contribution of the different areas of Primary Education to their development. Organizational and functional measures that favour their development. Methodology and evaluation"), for the development of written expression ("Topic 37. Development of written expression in Primary Education. Learning methods and strategies. Composition of different written texts. Use of information and communication technologies. Educational intervention strategies "), or in relation to the collection and processing of information in the area of Mathematics (topic 25 of the 2007 legislation remains, which now corresponds to topic 58). In any case, we can state, regarding all laws that, to the absence in the practical part (A) is added an exclusively theoretical approach to the agenda in relation to ICT, which means the digital competence of teachers is not really assessed.

Regarding the "Competition phase", there are some common elements in the calls for the different selection processes held since the 90s in the Valencian Community: on the one hand, ICTs are considered in the different scales (P) and, on the other hand, the score that can be obtained for ICT training is interchangeable (I) with a different training within the educational field.

In the configuration of the scales, it is possible to define some differences such as the place that ICT training occupies in the scale (Its inclusion in "Other merits" and "Academic and permanent training" varies according to the call) as well as the score that can be obtained with this training. As a noteworthy element, we could highlight that, from 2013, ORDER 30/2013, of April 26, which makes a call of examination to access into de Teaching Career for the acquisition of new specialties, an exclusive section of ICT is scored up to 0.25 . This can be compared to its previous inclusion in an item shared with other training issues such as school organization, psychopedagogy, Valencian ..., according to the specific call analysed. However, and despite the commitment to provide ITC with a score on its own, which reveals a clear intention of rising the importance given to ICT, the maximum score of the scale can still be reached despite having not scored in this matter.

In summary, the selection process does not evaluate the teaching digital competence beyond a theoretical knowledge that can be asked in the opposition phase of the test, being permanent training in ICT important but not essential regarding scored.

\section{Conclusions}

The digital competence of teachers has become a requirement at all educational levels to meet the demands of the knowledge society and the digital age. Hence, it has been regulated, especially in the last decade, setting reference frames with specific descriptors that serve as a guide and orientation for the performance of teachers' digital competence. In all of them, it can be observed that, beyond the knowledge about the use of a digital tool, the objective is to develop a competence: to use knowledge, skills and personal, social and/or methodological abilities, under terms of responsibility and autonomy, to develop actions that offer a satisfactory and quality response in a specific training context (Rangel, 2015).

At the level of Spanish educational legislation, the inclusion of a digital area is evident, also with regard to teacher training; Indeed, for students to analyse, interpret and build in new formats and technological codes, pedagogical scenarios are needed that involve active and constructive participation, with the help of ICT resources, which 
teachers must be prepared to handle in this digital literacy era (Manzano, 2015). This legislative change, taking into account the results, is produced fundamentally from the LOE, where the responsibility for training teachers in digital matters falls on the Administration, in accordance with the inclusion of ICT in all subjects that student's study (Ala-Mutka, Punie \& Redecker, 2008). The LOMCE, on the other hand, specifies the digital teaching competence as such, mentioning a change in the educational paradigm focused on the construction of a digital ecosystem, which makes it essential that the different dimensions involved in teacher training (instrumental, curricular, designer, criticism...) have to be considered (Cabero \& Martínez, 2019). Thus, and in the absence of development of the LOMLOE, we can affirm that the educational laws have been responding, progressively, to the needs of the context.

This change in the legislation and in teacher training requirements has necessarily required modifications in the initial teacher training and the curriculum in which it is based. The changes from the Plan of 2000 to the one of 2012, with the replacement of the subject "New technologies applied to education" by "Curriculum development and digital classrooms in Primary Education", implies a change of conception to understand ICT , not as a tool for application to the classroom, but from the didactic-pedagogical perspective, as a competence that requires the development of skills at the curricular level, design, evaluation and implementation, from a critical and constructive pedagogy adapted to the autonomous and creative development of the student body (Cabero \& Palacios, 2020). Although the inclusion of this single subject does not ensure the work of the different configurative dimensions of the digital teaching competence, it does offer an approach in accordance with the progress of the theoretical approaches. Along the same lines lies the concept of lifelong learning, which has been increasingly concerned with the inclusion of ICT in a meaningful and constructive way in the teaching-learning process (Sorroza, Jinez, Rodríguez, Caraguay \& Sotomayor, 2018), becoming an indispensable tool to thrive in the framework of digital competence.

This trend of progressive incorporation of ICT into legislation and training finds another key element in the selection processes and access to the Teaching Career. As it can be seen from the analysis carried out, the different exam calls pay increasing attention to technology, especially since 2007. This issue is reflected in its treatment of the topics and in the scale of the merits phase of the selection process. However, at no time is digital competence understood as a requirement for access to the body, nor is a score guaranteed (even as merit) in which the competence is truly evaluated and not theoretical knowledge that, frequently, is out of date.

Therefore, it is evident that there is no real correspondence between the legislative requirements at the curricular level, the initial teacher training plan and the content of the program and requirements in the access procedure to the Teaching Career. In effect, although a direction has been marked since the turn of the century, especially since the regulation of the LOE, and later with the LOMCE, which affects training plans and does so, more timidly, in the selection processes; the chain originated in the needs that arise from the digital society is slowing down along the path of legislation-training-access to the career. The foregoing means that teachers are supposed to teach their students a competence with scarce training which command, in any case, has not been necessary to demonstrate in order to access the profession they perform.

In the described context, the development of digital competence in teachings in a full sense (knowledge and general ability in the use of technology, communication, information management, security and legal aspects, problem solving, understanding of its social impact, creative creation content... according to Durán, Gutiérrez and Prendes (2016) is not guaranteed, unless, of course, permanent training plays its role in an extraordinarily satisfactory way. 


\section{Bibliographic references}

Agreda, M., Hinojo, M. A., \& Sola, J. M. (2016). Diseño y validación de un instrumento para evaluar la competencia digital de los docentes en la educación superior española. Pixel-Bit Revista de Medios y Educación, 49, 39-56. Retrieved from: https://recyt.fecyt.es/index.php/pixel/article/view/61713

Ala-Mutka, K., Punie, Y., \& Redecker, C. (2008). Digital competence for lifelong learning. Luxemburg: Office for Official Publications of the European Communities.

Cabero, J., \& Martínez, A. (2019). Las tecnologías de la información y comunicación y la formación inicial de los docentes. Modelos y competencias digitales. Profesorado, Revista de currículum y formación del profesorado, 23(3), 247-268. Retrieved from: https://recyt.fecyt.es/index.php/profesorado/article/view/74491/0

Cabero, J., \& Palacios, A. (2020). Marco Europeo de Competencia Digital Docente «DigCompEdu» y cuestionario «DigCompEdu Check-In». EDMETIC, Revista de Educación Mediática y TIC, 9(1), 213-234. Retrieved from: https://www.uco.es/ucopress/ojs/index.php/edmetic/article/view/12462

Cabero, J., Romero, R., \& Palacios, A. (2020). Evaluation of Teacher Digital Competence Frameworks Through Expert Judgement: the Use of the Expert Competence Coefficient. Journal of New Approaches in Educational Research, 9(2), 275-293. Retrieved from: https://naerjournal.ua.es/article/view/v9n2-9

Castro, A., \& Artavia, K.Y. (2020). Competencias digitales docentes: un acercamiento inicial. Revista Electrónica Calidad En La Educación Superior, 11(1), 47-80. Retrieved from: https://revistas.uned.ac.cr/index.php/revistacalidad/article/view/2932

Chib, A., Bentley, C., \& Wardoso, R. J. (2019). Entornos digitales distribuidos y aprendizaje: Empoderamiento personal y transformación social en colectivos discriminados. Comunicar, 58, 51-61. Retrieved from: https://www.revistacomunicar.com/index.php?contenido=detalles\&numero=58\&articulo=58-2019-05

Del Prete, A., \& Cabero, J. (2020). El uso del Ambiente Virtual de Aprendizaje entre el profesorado de educación superior: un análisis de género. RED. Revista de Educación a Distancia, 62(20). Retrieved from: https://revistas.um.es/red/article/view/400061

Durán, M., Gutiérrez, I., \& Prendes, M.P. (2016). Certificación de la competencia TIC del profesorado universitario. Diseño y validación de un instrumento. Revista Mexicana de Investigación Educativa, 21(69), 527-556. Retrieved from: https://www.redalyc.org/pdf/140/14045395008.pdf

Eurydice España-REDIE (2008). Un marco estratégico actualizado para la cooperación europea en el ámbito de la educación y la formación. Retrieved from: https://bit.ly/35WFpX5

Ferrari, A. (2013). DIGCOMP: A Framework for Developing and Understanding Digital Competence in Europe. Luxembourg: Publications Office of the European Union. Retrieved from: https://bit.ly/3hSvXq1

Gutiérrez, I, \& Serrano, J.L. (2016). Evaluation and development of digital competence in future primary school teachers at the University of Murcia. New Approaches in Educational Research, 5(1), 51-56. Retrieved from: https://naerjournal.ua.es/article/view/v5n1-8

Hooper, S., \& Rieber, L. P. (1995). Teaching with technology. In A. C. Ornstein (Ed.), Teaching: Theory into practice (pp. 154-170). Boston: Allyn and Bacon. 
Huberman, A.M., \& Miles, M.B. (2010). Métodos para el manejo y el análisis de datos. En C.A. Denman, \& J. A. Haro (Eds.), Por los rincones. Antología de métodos cualitativos en la investigación social (pp. 253-301). Sonora: El Colegio de Sonora.

Institute of Educational Technologies and Teacher Training (INTEF) (2017). Marco Común de Competencia Digital Docente. Retrieved from: https://bit.ly/3ctol6U

Kali, Y., Sagy, O., Benichou, M., Atias, O., \& Levin-Peled, R. (2019). Teaching expertise reconsidered: The Technology, Pedagogy, Content and Space (TPeCS) knowledge framework. British Journal of Educational Technology, 50(5), 2162-2177.

Koehler, M. J., Mishra, P., Kereluik, K., Seob, T. S., \&. Graham, C. R. (2014). The Technological Pedagogical Content Knowledge Framework. En J. M. Spector et al. (Eds.), Handbook of Research on Educational Communications and Technology (pp. 101-111). New York: Springer Science.

Krumsvik, R. (2011). Digital competence in Norwegian teacher education and schools. Högre utbildning, 1(1), 39-51. Retrieved from:

https://www.researchgate.net/publication/305360830_Digital_competence_in_the_Norwegian_teacher_ education_and_school

López, J.A., Campos, M.N., Aznar, I., \& Rodríguez, C. (2020). Competencia digital del profesorado para la atención al alumnado con dificultades de aprendizaje. Una revisión teórica. Revista Electrónica Interuniversitaria de Formación del Profesorado, 23(2), 143-154. Retrieved from: https://revistas.um.es/reifop/article/view/419171

Manzano, B. (2015). El desarrollo de la competencia digital en la normativa curricular española. Opción, 31(1), 828-850. Retrieved from: https://bit.ly/2FQAADZ

Martínez, R., Castellanos, M.A., \& Chacón, J.C. (2014). Métodos de investigación en Psicología. Madrid: EOS Universitaria.

McGarr, O., \& McDonagh, A. (2019). Digital Competence in Teacher Education, Output 1 of the Erasmus funded Developing Student Teachers' Digital Competence (DICTE) project. Retrieved from: https://bit.ly/2RMQQYS

Padilla, A. L., Gámiz, V. M., \& Romero, M. A. (2018). Selección de categorías para el estudio de la evolución de la competencia digital docente del profesorado en Educación Superior. Revista Interuniversitaria De Investigación En Tecnología Educativa, 5, 55-67. Retrieved from: https://revistas.um.es/riite/article/view/327881

Peñalva, A., Napal, M., \& Medioroz, A.M. (2018). Competencia digital y alfabetización digital de los adultos (profesorado y familias). International Journal of New Education, 1(1). Retrieved from: https://revistas.uma.es/index.php/NEIJ/article/view/4892

Pozo, S., López, J., Fernández, M. \& López, J.A. (2020). Análisis correlacional de los factores incidentes en el nivel de competencia digital del profesorado. Revista Electrónica Interuniversitaria de Formación del Profesorado, 23(1), 143-159. Retrieved from: https://revistas.um.es/reifop/article/view/396741

Prendes, M.P., Gutiérrez, I. y Martínez, F. (2018). Competencia digital: una necesidad del profesorado universitario en el siglo XXI. RED. Revista de Educación a Distancia, 56. Retrieved from: https://revistas.um.es/red/article/view/321591 
Rangel, A. (2015). Competencias docentes digitales: propuesta de un perfil. Píxel-Bit. Revista De Medios Y Educación, 46, 235-248. Retrieved from: https://recyt.fecyt.es/index.php/pixel/article/view/61622

Ruiz, A., Medina, M., Pérez, E., \& Medina, A. (2020). Formación del Profesorado Universitario en la Competencia Digital. Píxel-Bit. Revista De Medios Y Educación, 58, 181-215. Retrieved from: https://recyt.fecyt.es/index.php/pixel/article/view/74676

Sorroza, N.A., Jinez, J.P., Rodríguez J.E., Caraguay W.A., Sotomayor M.V. (2018). Las TIC y la resistencia al cambio en la Educación Superior. Revista Científica Mundo de la Investigación y el Conocimiento, 2(2): 47795. Retrieved from: https://recimundo.com/index.php/es/article/download/241/html?inline=1

Tejada, J. \& Pozos, K.V. (2018). Nuevos escenarios y competencias digitales docentes: hacia la profesionalización docente con TIC. Profesorado. Revista de curriculum y formación del profesorado, 2(1), 25-51. Retrieved from: https://recyt.fecyt.es/index.php/profesorado/article/view/63620

United Nations Educational, Scientific and Cultural Organization (UNESCO) (2019). Marco de competencias de los docentes en materia de TIC. Retrieved from: https://bit.ly/3cq5oar

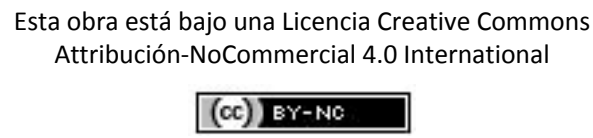

\section{(cc) BY-NC}

